\title{
Analisis Kepatuhan Wajib Pajak Bumi dan Bagunan Perdesaan dan Perkotaan (PBB P2) di Kecamatan Tutur Tahun 2017-2020
}

\author{
Farhad Chalid \\ Program Studi Administrasi Publik, Universitas Yudharta Pasuruan \\ farhadamudy@gmail.com
}

\begin{abstract}
This study aims to determine (1) the compliance of land and building taxpayers in Tutur District 20172020, (2) obstacles in realizing land and building taxpayer compliance in Tutur District, and (3) how to overcome obstacles in realizing taxpayer compliance. land and buildings in Tutur District. This study used a qualitative descriptive research design. Data were collected by means of documentation and interviews. The data analysis technique used is descriptive qualitative analysis. The results showed that (1) Compliance with land and building taxpayers in Tutur District 2017-2020, namely 2017 (58.44\%), 2018 (54.23\%), 2019 $(49.22 \%)$, and $2020(32.04 \%)$. (2) The obstacles experienced in realizing the compliance of land and building taxpayers in Tutur District are the lack of understanding and awareness of taxpayers and the level of income of taxpayers. (3) How to overcome obstacles in realizing land and building taxpayer compliance is by providing socialization to taxpayers, and by checking tax rates.
\end{abstract}

Keywords: land and building taxpayer compliance, obstacles in realizing land and building taxpayer compliance, and how to overcome obstacles in realizing taxpayer compliance

Abstrak. Penelitian ini bertujuan untuk mengetahui (1) kepatuhan wajib pajak bumi dan bangunan di Kecamatan Tutur tahun 2017-2020, (2) hambatan dalam merealisasi kepatuhan wajib pajak bumi dan bangunan di Kecamatan Tutur, dan (3) cara menanggulangi hambatan dalam merealisasi kepatuhan wajib pajak bumi dan bangunan di Kecamatan Tutur. Penelitian ini menggunakan desain penelitian deskriptif kualitatif. Data dikumpulkan dengan metode dokumentasi dan wawancara. Teknik analisis data yang digunakan adalah analisis deskriptif kualitaif. Hasil penelitian menunjukkan bahwa (1) Kepatuhan wajib pajak bumi dan bangunan di Kecamatan Tutur tahun 2017-2020 yaitu tahun 2017 (85.62\%), 2018 (87.32\%), 2019 (75.99\%), dan 2020 (68.76\%). (2) Hambatan yang dialami dalam merealisasikan kepatuhan wajib pajak bumi dan bangunan di Kecamatan Tutur adalah kurangnya pemahaman dan kesadaran wajib pajak, dan tingkat pendapatan wajib pajak. (3) Cara menanggulangi hambatan dalam merealisasikan kepatuhan wajib pajak bumi dan bangunan adalah dengan cara memberikan sosialisasi kepada wajib pajak, dan dengan memeriksa tarif pajak.

Kata Kunci: kepatuhan wajib PBB, hambatan dalam merealisasi kepatuhan pembayaran PBB, dan cara menanggulangi hambatan dalam merealisasi kepatuhan pembayaran $\mathrm{PBB}$

\section{PENDAHULUAN}

Pajak Bumi dan Bangunan merupakan jenis pajak daerah yang sepenuhnya diatur oleh pemerintah dalam menentukan besar pajaknya, pajak ini penting untuk pelaksanaan dan peningkatan pembangunan serta meningkatkan kemakmuran dan kesejahteraan rakyat (Amanah, 2015). Oleh karena itu perlu adanya peningkatan peran serta masyarakat. Menurut Puspita (2014), pajak ini bersifat kebendaan, artinya besaran pajak terutang ditentukan oleh keadaan objek yaitu bumi/tanah/dan atau bangunan.

Bumi dan bangunan memberikan keuntungan dan kedudukan sosial ekonomi yang lebih baik bagi orang/badan yang mempunyai suatu hak atasnya atau memperoleh manfaat darinya (Jati, 2016). Oleh sebab itu, mereka diwajibkan untuk memberikan sebagian dari manfaat yang diperolehnya kepada negara melalui pajak. Hasil penerimaan Pajak Bumi dan Bangunan (PBB) ditujukan untuk kepentingan masyarakat daerah yang diduduki (Hidayanti, 2011).

Dalam rangka meningkatkan penerimaan daerah dari sektor perpajakan, maka pemerintah juga melakukan amandemen pada peraturan perundang-undangan di bidang pajak dan retribusi daerah. Tindakan pemerintah tersebut merupakan peran serta pemerintah dan dukungan amandemen undangundang yang telah dibuat oleh pemerintah Indonesia berkaitan dengan pajak adalah amandemen pada Undang-Undang Nomor 28 Tahun 2009 tentang Pajak Bumi dan Bangunan (Widiastuti dan Laksito, 2014).

Untuk meningkatkan penerimaan Pajak Bumi dan Bangunan (PBB) perlu adanya peningkatan kesadaran dan kepedulian masyarakat di bidangperpajakan. Sistem Pemungutan Pajak yang digunakan dalam membayarPajak Bumi dan Bangunan (PBB) adalah Official Assessment System,sistem pemungutan tersebut dimana jumlah pajak yang harus dilunasi atauterutang oleh wajib pajak dihitung dan ditetapkan oleh Fiskus/aparat pajak(Jati, 2016).

Dalam Official Assessment System ini wajib pajak bersifat pasif sedangkan Fiskus bersifat aktif (Jati, 2016). Walaupun wajib pajakbersifat pasif, tanpa adanya kesadaran wajib pajak untuk mengetahuibesarnya jumlah dan membayar pajaknya, maka akanmengakibatkanturunnya kepatuhan wajib pajak dalam membayar pajak terutama Pajak Bumidan Bangunan ini (PBB). Berdasarkan pernyataan tersebut menunjukkanbahwa meskipun perhitungan Pajak Bumi dan Bangunan (PBB) 
dilakukan secara Official Assessment System juga diperlukan kepatuhan dalam pembayarannya (Wardani, 2015).

Pengetahuan tentang peraturan perpajakan akan meningkatkan kemauan Wajib Pajak untuk membayar pajak (Suyono, 2016). Karena Wajib Pajak yang sudah mengerti peraturan perpajakan akan berpikiran untuk lebih baik membayar pajak daripada terkena sanksi pajak (Handayani, 2012). Pengetahuan perpajakan yang dimiliki oleh Wajib Pajak merupakan hal mendasar yang harus dimiliki oleh Wajib Pajak karena tanpa adanya pengetahuan tentang pajak, Wajib Pajak akan mengalami kesulitan dalam menjalankan kewajiban perpajakannya (Kristanty, 2014).

Menurut Laksito (2014), pada dasarnya faktor yang menghambat pembayar pajak adalah masalah kesadaran masyarakat, dimana masyarakat perlu diberi pengarahan bahwa pajak merupakan kewajiban dan hak setiap warga negara untuk ikut serta dalam pembangunan. Kesadaran dalam membayar pajak muncul dari motivasi wajib pajak (Yusnidar, 2015). Jika kesadaran Wajib Pajak tinggi yang berasal dari motivasi untuk membayar pajak, maka kepatuhan untuk membayar pajak pun akan tinggi dan pendapatan untuk daerah sektor pajak semakin meningkat (Handayani, 2012).

Terdapat satu faktor eksternal yang juga mempengaruhi wajib pajak dalam patuh tidaknya membayar Pajak Bumi dan Bangunan. Faktor tersebut adalah sanksi pajak. Menurut Yusnidar (2015), fungsi sanksi adalah digunakan sebagai cara untuk mengatur sekelompok populasi untuk memenuhi aturan yang ditentukan. Sanksi ditujukan kepada wajib pajak yang tidak mematuhi aturan perpajakan atau melakukan pelanggaran berupa kecurangan terhadap peraturan perpajakan yang berlaku saat ini (Yadnyana, 2016).

Bentuk sosialisasi perpajakan bisa dilakukan dengan penyuluhan. Sosialisasi yang diberikan kepada masyarakat dimaksudkan untuk memberikan pengertian kepada masyarakat akan pentingnya membayar pajak. Dengan sosialisasi ini masyarakat menjadi mengerti dan paham tentang manfaat membayar pajak serta sanksi jika tidak membayar pajak. (Winerungan, 2013).

Surat Pemberitahuan Pajak Terhutang, yang selanjutnya disingkat SPPT adalah surat yang digunakan untuk memberitahukan besarnya Pajak Bumi dan Bangunan yang terutang kepada Wajib Pajak (Pasal 1 Angka 54 UU Nomor 28 Tahun 2009 Tentang Pajak Daerah Dan Retribusi Daerah). Wajib pajak yang mendapatkan SPPT wajib membayarkanpajak terutang sesuai dengan besarnya pengenaan pajak yang terdapat dalam SPPT. SPPT diterbitkan berdasarkan data objek pajak yang ada pada Dinas Pendapatan Pengelolaan dan Aset Daerah. (Yusnidar, 2015).

Penyebab lain rasio kepatuhan adalah masih banyak masyarakat yang beranggapan negatif terhadap petugas pajak, hal ini memerlukan upaya untuk meningkatkan pelayanan yang baik agar terciptanya kepuasan wajib pajak dalam pelaksanaan perpajakan. Kualitas pelayanan didefinisikan sebagai persepsi seluruh wajib pajak atau penilaian wajib pajak dari tingkat administrasi pajak dengan diukur melalui metode Servqual dengan lima dimensi yaitu bukti fisik, keandalan, daya tanggap, jaminan dan empati. Harmawati dan Yadnyana (2016).

Kecamatan Tutur merupakan salah satu Kecamatan di Kabupaten Pasuruan yang setiap tahunya terus mengalami perkembangan infrastuktur. Adanya pembangunan infrastuktur tersebut perlu didampingi dengan dana yang memadai. Salah satunya adalah tuntutan bagi Kecamatan Tutur untuk dapat membiayai sebagian besar anggaran pembangunanya melalui kewenangan yang diberikan dalam otonomi daerah dengan menggali segala sumber pendapatan yang potensial dari daerah itu sendiri berdasarkan peraturan perundang undangan yang berlaku.

Dalam perpajakan kita dapat memberi pengertian bahwa kepatuhan perpajakan merupakan ketaatan, tunduk, dan patuh serta melaksanakan ketentuan perpajakan. Jadi wajib pajak yang patuh adalah wajib pajak yang taat dan memenuhi serta melaksanakan kewajiban perpajakan sesuai dengan ketentuan peraturan perundang-undangan perpajakan.

Peningkatan jumlah wajib pajak bumi dan bangunan di Kecamatan Tutur yang semakin tahun terus mengalami Penurunan, sehingga secara otomatis akan berdampak pada bertambahnya SPPT yang disebar. Dengan penurunan SPPT seharusnya kepatuhan wajib pajak yang membayar PBB juga ikut mengalami kenaikan, akan tetapi kesadaran wajib pajak dalam memenuhi kewajibanya sangat minim. Berdasarkan data PBB tahun 2017 terdapat 33.719 SPPT yang tersebar di Kecamatan Tutur, namun hanya 29.529 wajib pajak yang menyampaikan SPPT. Hal ini menunjukan bahwa tingkat kepatuhan wajib pajak bumi dan bangunan di Kecamatan Tutur hanya 85,62\% dari jumlah SPPT yang terdaftar.

Tugas utama dari Petugas PBB P2 Kecamatan adalah sebagai perantara untuk menyampaikan SPPT pajak bumi dan bangunan kepada masyarakat yang berada di Kecamatan Tutur. Tahun 2017-2020 jumlah SPPT yang disebar terus meningkat namun realisasinya penerimaan pajak PBB terus mengalami penurunan pada tahun 2017 jumlah wajib pajak adalah 33.719 sedangkan yang terealisasi hanya 29.529, tahun 2018 jumlah wajib pajak 33.729 yang terealisasi 31.044, tahun 2019 jumlah wajib pajak 33.665 yang terealisasi 27.687, dan tahun 2020 jumlah wajib pajak 33.641 yang terealisasi 24.259. Ketidak patuhan wajib pajak dalam membayar pajak bumi dan bangunan akan berpengaruh terhadap tidak tercapainya target penerimaan pajak yang telah dirancang pemerintah untuk mendanai anggaran belanja daerah. Ketidak tercapaian ini akan berdampak tidak tersedianya dana untuk pembangunan infrastruktur. 


\section{METODE PENELITIAN}

Dalam penelitian ini pendekatan yang dilakukan adalah melalui pendekatan kualitatif. Artinya data yang dikumpulkan bukan berupaangka-angka, melainkan data tersebut berasal dari naskah wawancara, catatan lapangan, dokumen pribadi, catatan memo, dan dokumen resmi lainnya. Sehingga yang menjadi tujuan dari penelitian kualitatif ini adalah ingin menggambarkan realita empirik di balik fenomena secara mendalam, rinci dan tuntas. Oleh karena itu penggunaan pendekatan kualitatif dalam penelitian ini adalah dengan mencocokkan antar arealita empirik dengan teori yang berlaku dengan menggunakan metode deskriptif.

Adapun jenis penelitian ini adalah penelitian kualitatif deskriptif. Penelitian deskriptif dalam hal ini adalah untuk Menganalisis Kepatuhan Wajib Pajak Bumi dan Bangunan Perdesaan dan Perkotaan (PBBP2) di Kecamatan Tutur Tahun 2017-2020 sehingga dapat menemukan strategi yang tepat untuk meningkatkan penerimaan Pajak Bumi Bangunan Pedesaan dan Perkotaan (PBB-P2).

\section{HASIL PENELITIAN DAN PEMBAHASAN}

\section{Hasil Penelitian}

Berikut disajikan hasil penelitian jumlah wajib pajak bumi dan bangunan, data realisasi penerimaan PBB, SPPT tidak tertagih dan persentase kepatuhan wajib pajak dari tahun 2017-2020 nampak pada tabel 1.

Tabel 1 Kepatuhan Wajib Pajak Bumi dan Bangunan di Kecamatan Tutur Tahun 2017-2020.

\begin{tabular}{|l|c|c|c|l|}
\hline Tahun & $\begin{array}{c}\text { Jumlah } \\
\text { WP }\end{array}$ & $\begin{array}{c}\text { Penerimaan } \\
\text { PBB }\end{array}$ & $\begin{array}{c}\text { SPPT tdk } \\
\text { Tertanggung }\end{array}$ & $\begin{array}{l}\text { Presentasi } \\
\text { WP }(\%)\end{array}$ \\
\hline 2017 & 33.719 & 1.076 .652 .988 & 921.866 .107 & 85.62 \\
\hline 2018 & 33.729 & 1.077 .061 .700 & 940.523 .382 & 87.32 \\
\hline 2019 & 33.665 & 1.190 .246 .415 & 904.429 .355 & 75.99 \\
\hline 2020 & 33.641 & 1.404 .338 .402 & 965.616 .931 & 68.76 \\
\hline
\end{tabular}

Berdasarkan tabel 1 di atas diperoleh data bahwa jumlah wajib pajak bumi dan bangunan yang terdaftar di Kecamatan Tutur tahun 2017 yaitu sebesar 33.719. Dari jumlah wajib pajak tersebut realisasi penerimaan PBB sebesar 29.529, sedangkan jumlah SPPT tidak tertagih sebesar 4.190, dari hasil tersebut diperoleh persentase kepatuhan wajib pajak bumi dan bangunan di kecamatan Tutur Pada tahun 2017 mencapai $85.62 \%$. Pada tahun 2018 jumlah wajib pajak bumi dan bangunan yang terdaftar di Kecamatan Tutur yaitu sebesar 33.729. Dari jumlah wajib pajak tersebut realisasi penerimaan PBB sebesar 31.044. sedangkan jumlah SPPT tidak tertagih sebesar 2.685. dari hasil tersebut diperoleh persentase kepatuhan wajib pajak bumi dan bangunan di Kecamatan Tutur Pada tahun 2018 mencapai 87.32\%.

Tahun 2019 jumlah wajib pajak bumi dan bangunan yang terdaftar di Kecamatan Tutur yaitu sebesar 33.665, dari jumlah wajib pajak tersebut realisasi penerimaan PBB sebesar 27.687, sedangkan jumlah SPPT tidak tertagih sebesar 5.978, dari hasil tersebut diperoleh persentase kepatuhan wajib pajak bumi dan bangunan di kecamatan Tutur Pada tahun 2019 mencapai $75.99 \%$. dan tahun 2020 jumlah wajib pajak bumi dan bangunan yang terdaftar di Kecamatan Tutur yaitu sebesar 33.641, dari jumlah wajib pajak tersebut realisasi penerimaan PBB sebesar 24.259, sedangkan jumlah SPPT tidak tertagih sebesar 9.382, dari hasil tersebut diperoleh persentase kepatuhan wajib pajak bumi dan bangunan di Kecamatan Tutur Pada tahun 2020 mencapai 68.76\%.

Adapun hambatan yang dihadapi dalam Merealisasikan Kepatuhan Wajib Pajak Bumi dan Bangunan di Kecamatan Tutur adalah sebagai berikut:

1) Kurangnya pemahaman dan kesadaran wajib pajak terhadap pentingnya peran pajak bagi pembangunan daerah. Penyebab dari menurunnya tingkat nilai penerimaan PBB adalah adanya keanekaragaman tingkat pendidikan di dalam masyarakat. Semakin pahamnya wajib pajak atas ketentuan maupun peraturan perpajakan yang berlaku, maka wajib pajak akan lebih sadar dalam memenuhi kewajibannya untuk membayar pajak yaitu PBB. Selain pemahaman dan kesadaran yang dimiliki wajib pajak mengenai perpajakan, kepatuhan wajib pajak juga harus diperhatikan oleh segenap instansi yaitu Kecamatan Tutur dalam proses pembayaran atau pelunasan pajak. Sebagaimana telah dipaparkan di atas, maka perlu diperhatikan pemahaman wajib pajak, kesadaran perpajakan wajib pajak serta kepatuhan wajib pajak yang berpengaruh terhadap realisasi penerimaan PBB.

2) Tingkat pendapatan wajib pajak yang rendah. Berdasarkan hasil wawancara kepada petugas PBB P2 di Kecamatan Tutur disebukkan bahwa dalam meningkatkan kepatuhan wajib pajak dalam membayar pajak PBB tidaklah mudah, faktor ekonomi merupakan hal yang sangat fundamental dalam hal melaksanakan kewajiban perpajakan. Masyarakat yang kurang mampu akan mengalami kesulitan untuk membayar pajak PBB. Kebanyakan wajib pajak akan memenuhi kebutuhan hidup 
baik itu kebutuhan primer, sekunder, maupun tersier terlebih dahulu sebelum membayar pajak, karenanya tingkat pendapatan seseorang dapat mempengaruhi kepatuahan wajib pajak tersebut.

3) Ketidak konsekuensinya petugas PBB P2 Desa dalam menyetoran Wajib Pajak

4) Keterlambatan pendistribusian SPPT dari Dinas Pendapatan Daerah Kabupaten Pasuruan ke Kecamatan

5) Keterlambatan Penyampaian SPPT dari petugas Desa ke Wajib Pajak

6) Masih banyaknya dijumpai kesalahan data di SPPT antara lain :

- Kesalahan Luas

- Kesalahan Nama

- Pajak tidak sesuai dengan objek yang ada

7) Kurang pahamnya petugas pajak Desa dengan Data Tanah yang ada di SPPT hal ini karena hampir 60\% petugas di Desa merupakan Perangkat Desa

8) Kondisi cuaca yang kurang baik sehingga berpengaruh pada hasil pertanian yang merupakan mata pencaharian utama wajib pajak

9) Situasi Pandemi Covid 19 juga berpengaruh terhadap intensifikasi PBB yaitu :

- Kurangnya sosialisasi

- Bebrapa petugas disibukkan dengan penanganan covid 19

10) Kurangnya Koordinasi dan penekanan antar petugas serta kurangnya penjelasan mengenai pentingnya pajak dan sangsi keterlambatan

11) Terlambatnya distribusi bantuan dari Pemerintah ke Pemerintahan Desa (DD, ADD dan bantuan lainnya) sehingga di beberapa Desa untuk sementara meminjam Dana PBB

Meskipun dalam merealisasikan kepatuhan wajib pajak bumi dan banguana menemui hambatan, berdasarkan hasil wawancara penulis dengan pihak terkait Sedahan Kecamatan Tutur hambatan yang dialami dalam merealisasikan kepatuhan wajib pajak bumi dan bangunan dapat diminimalisi dengan cara sebagai berikut :

1) Peran aktif pemerintah untuk menyadarkan masyarakat akan pajak sangat diperlukan baik berupa penyuluhan/sosialisasi rutin ataupun berupa pelatihan secara intensif agar kesadaran masyarakat untuk membayar pajak dapat meningkat atau dengan kebijakan perpajakan dapat digunakan sebagai alat untuk menstimulus atau merangsang wajib pajak agar melaksanakan dan atau meningkatkan kesadaran dalam membayar perpajakan. Beberapa bentuk kesadaran dalam membayar pajak. Terdapat tiga bentuk kesadaran utama terkait pembayaran pajak, yaitu: (1) Kesadaran bahwa pajak merupakan bentuk partisipasi dalam menunjang pembangunan negara. Dengan menyadari hal ini, wajib pajak mau untuk membayar pajak karena merasa tidak dirugikan dari pemungutan pajak yang dilakukan. (2) Kesadaran bahwa penundaan pembayaran pajak dan pengurangan beban pajak sangat merugikan negara. wajib pajak mau membayar pajak karena memahami bahwa penundaan pembayaran pajak dan pengurangan beban pajak berdampak pada berkurangnya sumber daya finansial yang dapat mengakibatkan terhambatnya pembangunan negara. (3) Kesadaran bahwa pajak ditetapkan dengan Undang-Undang dan dapat dipaksakan. wajib pajak akan membayar pajak karena pembayaran pajak disadari memiliki landasan hukum yang kuat dan merupakan suatu kewajiban mutlak setiap warga negara.

2) Permasalahan mengenai tingkat pendapatan wajib pajak harus ditintaklanjuti yaitu dangan melakukan pemeriksaan kembali tarif pajak yang dikenakan terhadap wajib pajak. jumlah tarif pajak yang dikenakan saat ini terhadap wajib pajak di Kecamatan Tutur masih dirasa cukup tinggi. 


\section{Pembahasan}

Berdasarkan grafik 1 diketahui bahwa persentase kepatuhan wajib pajak bumi dan bangunan di Kecamatan Tutur tahun 2017-2020 sebagai berikut :

\section{Grafik 1}

Tingkat Kepatuhan Wajib Pajak

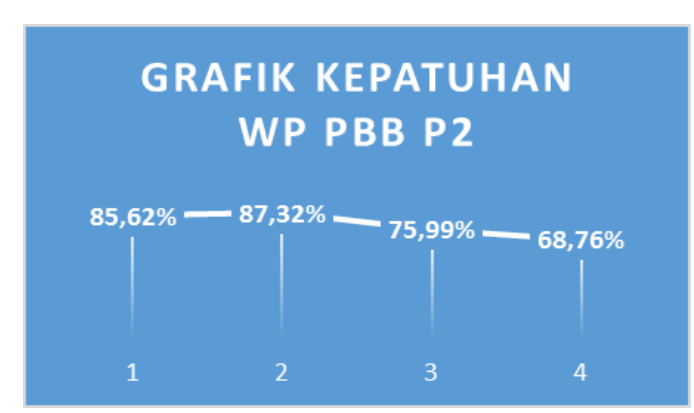

Dari grafik 1 di atas menunjukan persentase kepatuhan wajib pajak bumi dan bangunan di Kecamatan Tutur tahun 2017 sampai dengan 2020 terus mengalami penurunan, di tahun 2017 persentase kepatuhan pajak bumi dan bangunan sebesar $85.62 \%$, berikutnya di tahun 2018 persentase kepatuhan pajak bumi dan bangunan sebesar 87.32\%, tahun 2019 persentase kepatuhan pajak bumi dan bangunan mencapai $75.99 \%$, sedangkan penurunan persentase kepatuhan bumi dan bangunan kembali terjadi ditahun 2020 yaitu sebesar 68.76\%. Pajak bumi dan bangunan mempunyai peran penting bagi membangunan daerah, apabila masyarakat tidak taat akan pajak maka seluruh kegiatan daerah akan sulit terpenuhi misalnya kurangnya fasilitas umum, infrastruktur seperti jalan, jembatan, sekolah, rumah sakit dan puskesmas. Sesuai dengan teori yang dikemukakan oleh Mardiasmo (2011:335) Pajak Bumi dan Bangunan (PBB) merupakan sumber penerimaan utama Daerah yang digunakan untuk kepentingan infrastruktur pemerintah guna kelangsungan daerah dan meningkatkan kesejahreraan masyarakat.

Berdasarkan penelitian yang dilakukan penulis melalui metode wawancara, ditemukan bahwa hambatan yang dialami oleh Petugas PBB di Kecamatan Tutur secara umum adalah. (1) kurangnya pemahaman dan kesadaran wajib pajak terhadap pentingnya kepatuhan dalam menbayar pajak bumi dan bangunan. Penyebab dari menurunnya tingkat nilai penerimaan PBB tersebut adalah adanya keanekaragaman tingkat pendidikan di dalam masyarakat. (2) tingkat pendapatan wajib pajak yang rendah. Berdasarkan hasil wawancara kepada Petugas PBB di Kecamatan Tutur disebutkan bahwa dalam meningkatkan kepatuhan wajib pajak dalam membayar pajak PBB tidaklah mudah. Menurut Khilik (2020) menyatakan bahwa "masyarakat tidak akan menemui kesulitan dalam memenuhi kewajiban membayar pajaknya kalau nilai yang harus dibayar itu masih di bawah penghasilan yang sebenarnya mereka peroleh secara rutin. faktor ekonomi merupakan hal yang sangat fundamental dalam hal melaksanakan kewajiban."

Hambatan yang muncul dalam merealisasikan kepatuhan wajib pajak bumi dan bangunan di Kecamatan Tutur dapat ditanggulangi dengan cara (1) kegiatan sosialisasi adalah suatu upaya untuk memberikan pengertian, informasi, dan pembinaan kepada masyarakat pada umumnya dan wajib pajak pada khususnya mengenai segala sesuau yang berhubungn dengan perpajakan. Wajib pajak mengetahui dan memahami peraturan perpajakan melalui sosialisasi yang dilakukan oleh Kantor Pelayanan Pajak dan yang paling penting adalah wajib pajak mengetahui dan memahami peraturan pajak melalui training perpajakan yang mereka ikuti. Mencegah wajib pajak melakukan tindakan yang mengurangi kepatuhan atas kewajiban perpajakannya dapat dicegah dengan memberikan sosialisasi secara intensif kepada wajib pajak. (2) dangan melakukan pemeriksaan kembali tarif pajak yang dikenakan terhadap wajib pajak. jumlah tarif pajak yang dikenakan harus sesuai dengan NJOP dan Pendapatan Bumi dan Bangunan yang mereka miliki. Sehingga tidak terjadi pelanggaran dalam kepatuhan wajib pajak. Pemerintah biasanya menetapkan tarif pajak yang tinggi tetapi disisilain penerapan tarif pajak mempengaruhi kepatuhan wajib pajak dalam memenuhi kewajiban perpajakan karena mendorong wajib pajak untuk tidak mematuhi kewajiban perpajakannya.

\section{PENUTUP}

Kepatuhan wajib pajak bumi dan bangunan di Kecamatan Tutur dari tahun 2017 sampai dengan tahun 2020 terus mengalami penurunan hal ini dibuktikan dari persentase kepatuhan wajib pajak yaitu pada tahun 2017 (58.44\%), tahun 2018 (54.23\%), tahun 2019 (49.22\%), dan pada tahun 2020 (32.04\%). Adapun hambatan yang dialami dalam merealisasikan kepatuhan wajib pajak bumi dan bangunan di Kecamatan Tutur yaitu a) kurangnya pemahaman dan kesadaran wajib pajak, b) tingkat pendapatan wajib pajak. Untuk menanggulangi hambatan dalam merealisasikan kepatuhan wajib pajak bumi dan bangunan dengan beberapa cara yaitu a) sosialisasi dari pihak pemerintah, b) dengan memeriksa tarif pajak.

Untuk kurangnya pemahaman dan kesadarn wajib pajak perlu dilakukan sosialisasi dari pihak terkait yaitu pemerintah secara umum dan masingmasih Kantor Palayanan Pajak yang ada. Sehingga wajib pajak biasa memahami dan sadar pentingnya peran pajak bagi perkembangan infrastruktur daerah. 
Untuk tingkat pendapatan wajib pajak Kantor Pelayanan Pajak perlu mengkaji ulang mengenai tarif yang akan dikenakan kepada wajib pajak. sehingga pendapatan pajak bisa optimal.

\section{UCAPAN TERIMA KASIH}

Dalam penyusunan jurnal penelitianini tidak terlepas dukungan dari berbagai pihak.Peneliti secara khusus mengucapkan terima kasih yang sebesar-besarnya kepada semua pihak yang telah membantu. Peneliti banyak menerima bimbingan, petunjuk dan bantuan serta dorongan dari berbagai pihak baik yang bersifat moral maupun material. Pada kesempatan ini penulis menyampaikan rasa terima kasih yang sebesarbesarnya kepada:

1. Allah SWT dengan segala rahmat serta karunia-Nya yang memberikan kekuatan bagi peneliti dalam menyelesaikan jurnalini.

2. Kepada kedua orang tua tercinta yang selama ini telah membantu peneliti dalam bentuk perhatian, kasih sayang, semangat, serta doa yang tidak henti-hentinya mengalir demi kelancaran dan kesuksesan peneliti dalam menyelesaikan penelitian ini.

3. Kepada Bapak Aan Urwatul Ulum, M.KP selaku dosen pembimbing yang selalu memberikan bimbingan, arahan, dorongan, dan semangat kepada peneliti,sehingga jurnalini dapat terselesaikan.

4. Kepada Bapak Agus Prianto,MPA selaku kaprodi yang selalu memberikan bimbingan,arahan, dorongan, dan semangat.

5. Kepada pihak pemerintah Kecamatan Tutur yang telah memberikan kesempatan bagi peneliti untuk melakukan penelitian dan memperoleh data.

6. Serta masih banyaklagi pihak-pihak yang sangat berpengaruh dalam proses penyelesaian jurnal iniyang tidak bisa peneliti sebutkan satupersatu Akhirnya, peneliti berharap semoga jurnal penelitianini dapat bermamfaat bagi kita semuadan menjadi bahan masukan bagi pengembangdunia pendidikan.

\section{DAFTAR PUSTAKA}

Ariani, Dorothea Wahyu. 2003. Manajemen Kualitas Pendekatan Sisi Kualitatif. Yogyakarta: Ghalila Indonesia.

Irianto, Slamet Edi. 2011. Politik Perpajakan: Membangun Demokrasi Negara, UII Press, Yogyakarta.

Marihot, Siahaan P. 2010. Hukum Pajak Elementer Konsep Dasar Perpajakan Indonesia. Jakarta: Raja Grafindo Persada.

Pemerintah RI. Undang-Undang Nomor 12 tahun 1994 Tentang Perubahan Pertama Undang-Undang Nomor 12 Tahun 1985 Tentang Pajak Bumi dan Bangunan.

Pemerintah Daerah. Pemberian Stimulasi tentang Pajak Bumi dan Bangunan Kabupaten Pasuruan Nomer 63 Tahun 2018. Perda Kab. Pasuruan.

Pemerintah Daerah. Tata Cara Pemungutan Pajak Bumi dan Bangunan Kabupaten Pasuruan Nomer 61 Tahun 2012. Perda Kab .Pasuruan.

Suandy, Erly. 2011. Hukum Pajak, Jakarta: Selemba Empat.

Waluyo, 2011. Perpajakan Indonesia. Jakarta: Selemba Empat.

Amanah, L.dan Donovan, D.2015.Strategi pemungutan PBB sebagai upaya meningkatkan Pendapatan Asli Daerah di Kota Mojokerto.Jurnal Ilmu dan Riset Akuntansi,Vol. 4 No. 11.

Puspita (2014). " Analisis Jalur Pengaruh Sosialisasi Terhadap Kepatuhan Wajib Pajak Bumi dan Bangunan Kota Kediri dengan Kesdaran Sebagai Variabel Intervening” (Studi Empiris Pada Dinas Pendapatan Kota Kediri)

Budhiartama, I Gede Prayuda dan I Ketut Jati. 2016. Pengaruh Sikap, Kesadaran Wajib Pajak dan Pengetahuan Perpajakan pada Kepatuhan Membayar Pajak Bumi dan Bangunan. E-Jurnal Akuntansi Universitas Udayana. Vo1.5 No.2 ISSN: 1510-153

Hidayati, Iva Farida. 2014. Analisis Pengaruh Kesadaran Wajib Pajak, Pengetahuan dan Pemahaman Tentang Peraturan Perpajakan, Efektifitas Sistem Perpajakan, Pelayanan Fiskus, dan Sanksi Pajak Terhadap Kepatuhan Wajib Pajak Orang Pribadi (Studi Kasus pada KPP Pratama Surakarta). Skripsi (tidak dipublikasikan). Universitas Muhammadiyah, Surakarta.

Widiastuti dan Herry Laksito. 2014. Faktor -faktor yang Mempengaruhi Kepatuhan Pajak Bumi dan Bangunan (P-2).Jurnal Akuntansi Fakultas Ekonomika dan Bisnis Universitas Diponegoro. Vol.3, No.2, ISSN: 2337-3806.

Handayani Wahyu (2012), “Atribusi” diakses melalui http://blogwahyu statistika.blogspot.com/2013/02/pengertian-atribusi-psikologi.html pada 29 oktober2016

Harmawati dan I Ketut Yadnyana. 2016. Pengaruh Pemahaman Perpajakan, Kualitas Pelayanan, Ketegasan Sanksi Pajak, dan Pemeriksaan Pajak pada Kepatuhan Wajib Pajak PBB-P2 dengan Tingkat Pendidikan Sebagai Pemoderasi.E-Jurnal Ekonomi dan Bisnis Universitas Udayana. Vol.5 No.6 ISSN: 2337-3067. 
Winerungan, Oktaviane Lidya. 2013. Sosialisasi Perpajakan, Pelayanan Fiskus dan Sanksi Perpajakan Terhadap Kepatuhan WPOP di KPP Manado dan KPP Bitung. Jurnal EMBA. Vol.1 No.3 ISSN: 960-970.

Yusnidar, Johan, dkk. 2015. Pengaruh Faktor-Faktor YangMempengaruhi Kepatuhan Wajib Pajak Dalam Melakukan Pembayaran Pajak Bumi Dan Bangunan Pedesaan danPerkotaan.Jurnal Perpajakan (JEJAK) Vol. 1 No. 1 Januari 2015. 